\title{
National Commissions: Implications of Reconciliation
}

\author{
Lorenzo Cherubini, Ed.D. \\ Brock University, St. Catharines, Ontario, Canada
}

\begin{abstract}
.
It has been 25 years since the publication of the Report of the Royal Commission on Aboriginal Peoples (RCAP). The RCAP is widely considered a landmark document in Canadian history due, in part, to the extensive recommendations that were an outcome of nearly 200 hearings, countless testimonies, and multiple research reports. Nearly 20 years after the release of the RCAP report, another key commission - The Truth and Reconciliation Commission of Canada (TRC) published a six-volume report consisting of over 3,200 pages that provided a comprehensive historical account of Canada's residential school system and the need for and significance of reconciliation between Indigenous and non-Indigenous peoples of Canada. In terms of public perception, the TRC re-introduced Indigenous issues into Canadian consciousness. The intent of this analysis, therefore, is first to review the critical theories and anti-oppressive education perspectives that are critical of mainstream government initiated commissions as espousing a view of reconciliation as merely a romantic and relatively hollow concept meant to quell the array of tensions between Indigenous and non-Indigenous peoples. Second, this paper will use a post-colonial theoretical framework to discuss the implications of the aforementioned theories and then offer a series of key recommendations towards enacting meaningful change.
\end{abstract}

Keywords: Report of the Royal Commission on Aboriginal Peoples, The Truth and Reconciliation Commission of Canada, Indigenous and non-Indigenous peoples

\section{Introduction}

It has been 25 years since the publication of the Report of the Royal Commission on Aboriginal Peoples (RCAP, 1996). The RCAP is widely considered a landmark document in Canadian history due, in part, to the extensive recommendations that were an outcome of nearly 200 hearings, countless testimonies, and multiple research reports (Institute on Governance, 2015). Established in 1991, the Report was commissioned by Prime Minister Brian Mulroney in response to a land dispute between the Mohawk nation and the town of Oka in Quebec. The over 400 recommendations spoke directly to many key issues that implicated Indigenous and settler relations in Canada. Among other objectives, the Commission was tasked with investigating the conditions that would constitute "a fair and honourable relationship between the Aboriginal and non-Aboriginal people of Canada" (RCAP, 1996, x). 


\title{
2nd world conference on research in SOCIAL SCIENCES
}

\author{
19-21 March, 2021
}

Budapest, Hungary

Nearly 20 years after the release of the RCAP report, another key commission - The Truth and Reconciliation Commission of Canada (TRC) published a six-volume report consisting of over 3,200 pages that provided a comprehensive historical account of Canada's residential school system and the need for and significance of reconciliation between Indigenous and non-Indigenous peoples of Canada (Miller, 2019). The TRC exposes the brutality and oppression of church-operated residential schools that removed Indigenous children from their communities with the intent of assimilating them in Eurocentric learning and cultural traditions in deliberate acts of cultural genocide (Henderson \& Wakeham, 2009). Education represented the means by which colonizers stripped Indigenous children of traditional values and linguistic practices and used a western-based curriculum to mobilize assimilationist policies (Kumar, 2009). The creation of a TRC is considered a public recognition of historical wrongdoing by the colonial settlers on the First Peoples of this land and in many respects has assumed a symbolic importance for post-colonial Canadian identity (Hughes, 2012). The 94 Calls for Action from the Truth and Reconciliation Commission's Report (2015) include a call for educational responses to promote the reconciliation of Indigenous and non-Indigenous peoples and the reporting of the "post-apology progress on reconciliation" across all "sectors of Canadian society" (53i \& 53ii). The section Education for Reconciliation includes a Call to build "student capacity for intercultural understanding, empathy, and mutual respect" (63iii) while strengthening relationships of reconciliation (Cutrara, 2018).

In terms of public perception, the TRC re-introduced Indigenous issues into Canadian consciousness (Institute of Governance, 2015). However, the intent of this analysis is first, to review the critical theories and anti-oppressive education perspectives that are critical of mainstream government initiated commissions as espousing a view of reconciliation as merely a romantic and relatively hallow concept meant to quell the array of tensions between Indigenous and non-Indigenous peoples while resulting in little meaningful change (Davis et al., 2017; Freeman, 2014). Second, this paper will use a post-colonial theoretical framework to discuss the implications of the aforementioned theories and then offer a series of key recommendations.

\section{Context}

At the time, the RCAP marked the most far-reaching and expensive public inquiry in the history of Canada, with an estimated cost of approximately 60 million dollars (Andersen \& Denis, 2003). The RCAP Report outlines the four stages of Indigenous and non-Indigenous relations in Canada, including: separate worlds, nation-to-nation relations, displacement and assimilation, and renewal and renegotiation (RCAP, 1996; 5-18). The stages outline the decline of equitable relations during the post-contact era, and ultimately recommends a reevaluation of the systemic and institutional practices that marginalize Indigenous peoples (McGregor, 2011). It is believed that the principles and objectives related to nation-building were considered most significant to advancing the reconciliation between Indigenous and non-Indigenous peoples. The Commission identified healing, economic development, human resources development, and Aboriginal governance as the most pressing areas that needed actionable responses and outcomes (Institute on Governance, 2015).

Before RCAP, the Hawthorn Report and Berger Inquiry also investigated Indigenous peoples' realities in a variety of political, educational, environmental, land, and treaty 


\section{2nd world conference on research in SOCIAL SCIENCES}

\section{9-21 March, 2021}

Budapest, Hungary

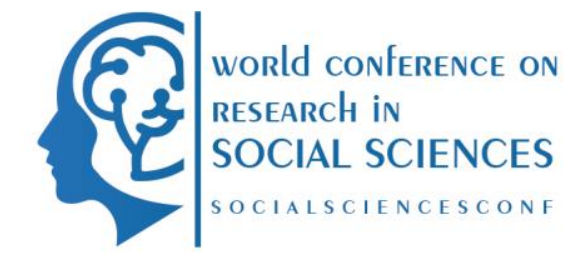

contexts; however, it is the RCAP that served as a guide for the respective development and implementation processes for the TRC (Hughes, 2012). It is noteworthy that despite the significant investment of time and energy into these inquiries leading up to the TRC, they have commonly resulted in the lack of meaningful action to address the inequities between Indigenous and non-Indigenous peoples (deLeeuw, 2017; Coulthard, 2017).

The Royal Commission on Aboriginal Peoples (1996) report underscored the significance of reconciliation in order to mend Indigenous and settler-relations and establish more equitable practices in terms of colonial government policy. The RCAP report,

concluded that the policy of assimilation was a complete failure and that Canada must look to the historical Treaty relationship to establish a new relationship between Aboriginal and non-Aboriginal peoples, based on the principles of mutual recognition, mutual respect, sharing, and mutual responsibility. The Royal Commission emphasized that Aboriginal peoples' right to self-determination is essential to a robust upholding of Canada's constitutional obligation to Aboriginal peoples and compliance with international human rights law. In other words, the RCAP report saw reconciliation as placing a heavy onus on the Government of Canada to change its conduct and to see the validity of the Aboriginal perspective of how the relationship should be in the future. (TRC, 2015; vol 1)

Like the RCAP invited Indigenous peoples to share their perspectives particularly as it concerned their experience with political tensions, the TRC also accounted for the voices and first-hand testimonials of Indigenous peoples' experiences in residential schools. It is important to distinguish, though, that the TRC is not considered a Royal Commission. Its origins are in the Indian Residential Schools Settlement Agreement (2005; see Reynaud, 2017) that heard claims and offered compensation to the living survivors of residential schools in Canada. The call for reconciliation in the TRC report speaks directly to the "ongoing process of establishing and maintaining respectful relationships" (TRC, 2015). The TRC recommended that all governments and parties consider the United Nations Declaration on the Rights and Indigenous Peoples as a framework for establishing reconciliation practices and policies in Canada:

A reconciliation framework is one in which Canada's political and legal systems, educational and religious institutions, the corporate sector and civic society function in ways that are consistent with the principles set out in the United Nations Declaration on the Rights of Indigenous Peoples, which Canada has endorsed. Together, Canadians must do more than just talk about reconciliation; we must learn how to practise reconciliation in our everyday lives - within ourselves and our families, and in our communities, governments, places of worship, schools, and workplaces. To do so constructively, Canadians must remain committed to the ongoing work of establishing and maintaining respectful relationships. (TRC, 2015, vol 1., p.21)

The respective 94 Calls to Action focus on issues related to education, language and culture, health and justice, Indigenous missing children, and sports and business, to name a few. In many respects, the recommendations established in the 1996 RCAP and the Calls to Action in the 2015 TRC report serve to re-contextualize Indigenous peoples' realities and problematize the power and authority of colonial paradigms and practices. 


\section{2nd world conference on research in SOCIAL SCIENCES}

\section{Discussion}

Various critical theories and anti-oppressive education perspectives suggest that the consciousness of contemporary Canadians is characteristic of hegemonic colonial narratives and histories and hence, contribute to Canadian's commitment to the status quo (Davies et al., 2017; Regan, 2010). It has been suggested that the findings and recommendations of the Royal Commission and the Truth and Reconciliation report are intended to be more than heart-wrenching testimonials of oppressive colonial practices and thus the expectation exists that non-Indigenous peoples and mainstream governments accept and act upon a sense of responsibility for these injustices (Czyzewski, 2011). Yet, from this critical perspective, it is argued that concepts of healing and reconciliation have a connotated focus or resolution that is certainly misleading in its suggestion that solutions precede action; in this way, the dialogue of reconciliation lessens the focus on Indigenous well-being and resituates it absolving non-Indigenous peoples and government from their continued responsibility to make amends for these injustices (Martin, 2009). Others have concluded that reconciliation is a multifaceted concept that has context-specific meanings, and that may have varied understandings within and between Indigenous communities and groups just as it may have between victims and beneficiaries of oppression (Nagy, 2012). Relatedly, endeavors premised on reconciliation have been accused of failing to honour the autonomy of the victims by ignoring their ideological and political uniqueness (Rymhs, 2006). It is argued that the connotations of reconciliation serve to alleviate the colonizers' sense of guilt and offer them a degree of reprieve from their responsibility to rectify the respective socio-political harms (Alfred, 2009; Nagy, 2012; Waziyatawin, 2009). In this respect, the limitations of both the RCAP and TRC include a certain degree of lack of action (Lightfoot, 2015; Waterstone \& deLeeuw, 2010). The commissions and reports, including some that preceded those published in 1996 and 2015, may not sufficiently disrupt the White patriarchal colonial narratives that can privilege settlers (Hunt, 2014; Hunt \& Holmes, 2015). Here, too, the criticism is directed at the inherent contradictions and tensions between the language and rhetoric of reconciliation and taking actual and meaningful action in response to the recommendations and calls - the same contradictions and tensions that often polarize the intentions and mandate of Indigenous peoples (as represented in the commission and report) and the response and commitment to change (or lack thereof) of non-Indigenous peoples and colonial governments (Davis et al., 2017).

Both the RCAP and TRC are high-level documents intended for the Indigenous and nonIndigenous peoples of Canada to re-evaluate personal, institutional, and government relations. Both documents include brave testimonials from Indigenous peoples that describe their oftenprecarious existence as the First Peoples of this land. Using a post-colonial theoretical framework, several key issues can be discussed. To begin, a strength of the RCAP's Recommendations and the TRC's Calls to Action is that they elicit a response from mainstream people, including all levels of colonial government (albeit to different extents). Given that the work and findings of the commissions were anchored in historical contexts, the resulting political, economic, socio-cultural, and educational implications of not taking decisive action to remedy the injustices experienced by Indigenous peoples in strikingly clear. The recommendations and calls to action embody a cautionary tone that cultivates an attitude of expectation that the historical wrongdoings experienced at the hands of colonial rule will be meaningfully addressed. The language of the recommendations and calls to action can be 


\title{
2nd world conference on research in SOCIAL SCIENCES
}

\author{
19-21 March, 2021
}

Budapest, Hungary

described as provocative in so far as it imparts the responsibility to act upon them directly to those who are in positions to enact change.

Moreover, both the RCAP and TRC reports underscore the contextual contemporary differences between Indigenous and non-Indigenous peoples in Canada. In doing so, the ramifications of ignoring these differences (including the gaps in health care, social services, and education, to name a few) have consequences for Indigenous and non-Indigenous peoples alike. The historic conditions described in both documents frame the contemporary realities that contribute to the prosperity and sustainability of all Canadians. While an interpretation of these documents from a colonial perspective may raise questions about the feasibility of the issues related to Indigenous self-determination as they are captured in the recommendations and calls to action, far less speculation can be drawn toward the adverse implications on the Canadian economy if such inequities continue to be ignored. Just as colonial systems of oppression can be said to be interrelated, so too can social and economic stability. The respective findings and themes of the commissions are interwoven and integrate historical and contemporary realities that position the obligation to respond and enact change on those areas of concern in the hands of settler-Canadians. Such an obligation, one would surmise, includes distinguishing a thoughtful and critical interpretation to the key issues raised in these reports, and then extending that knowledge into a decisive and strategic course of action. Canadians can no longer afford to simply placate the interests and needs of Indigenous peoples, nor can they (as the critical theorists argue) simply exploit the impetus for reconciliation for selfserving purposes. Indigenous peoples cannot be perceived as being responsible for promoting colonial and neo-liberal agendas to enhance the status of mainstream governments and society. Quite frankly, their contribution to the welfare of the country cannot be commodified.

\section{Recommendations and Conclusion}

While it is certainly beyond the scope of this analysis to address all the nuances of these extensive reports and inquiries, it may be useful to offer a few recommendations that stem from a broad reading of the respective recommendations and calls to action. It is important to note that the findings and outcomes of these reports are being presently interpreted amidst rapidly changing realities. It must be recognized, thus, that accounting for and understanding Indigenous peoples' perspectives may necessarily involve uncertain and confused local and national perspectives and interpretations. In some respects, settler-Canadians especially must admit that the issues are so highly complex and potentially daunting that they contribute to confused interpretations on how to take meaningful action. But we cannot fear the prospect of confusion. Nor can we avoid being entangled in frustration. This is difficult work that might challenge our pre-conceived assumptions and uninterrogated points-of-view.

For these reasons it is recommended that Indigenous and settler-Canadians revisit the recommendations and calls for action. But in doing so, that non-Indigenous people allow themselves to be vulnerable enough to be able to suspend their opinions, attitudes, and judgements and co-exist in potentially perplexing circumstances. In these vulnerable spaces, non-Indigenous peoples can better assess the prevalence of inequity as it emerges across all sectors of society. They can acquire a deeper understanding of the sometimes-underlying assumptions that harbour systemic racism against Indigenous people. The process can help clarify the traditional and epistemic values highlighted in the RCAP and TRC, and how 


\section{2nd world conference on research in SOCIAL SCIENCES}

history has had a dubious influence on contemporary oppressive practices experienced by Indigenous people.

It is further recommended that a framework for interpreting these realities be created that is unique to each sector and/or stakeholder group. Mainstream governments can communicate that the engagement in the framework is desirable and necessary. From a colonial perspective, the incentive to participate in the process already exists - access to equitable and accessible resources for Indigenous people will not limit their capacity and strain social assistance programs. The framework can draw upon numerous implications related to policy and practice, aim to increase understanding, and contribute to a heightened awareness of how colonial perspectives are privileged over others. The framework can empower key stakeholders of Indigenous and non-Indigenous communities to collaborate on mobilizing institutions in response to equitable practices across political and social systems. Most pertinent will be the sense of urgency to deal with these realities while potentially being suspended simultaneously in uncertainty and confusion.

Admittedly, the recommendations represent a challenging task since changing the consciousness of Canadians is clearly daunting. Yet, it is suggested that the process of addressing the recommendations remains realistic and recognizes that it can be intimidating for some to even consider, let alone discuss, their embedded attitudes of superiority and entitlement. Hence, to enact meaningful change will require a procedure (and essentially a framework) that invites vulnerability by ensuring open and transparent communication that is fact-based and accurately informed. There can be no deviation from this for the procedure and framework to proceed successfully. Each segment and sub-segment across society (as distinguished by the descriptions of the respective Calls to Action in the TRC report including health care, education, government, etc.) can then proceed to consider and discuss change in the general context of the common framework, while having the flexibility to tailor the process to accommodate the context of their stakeholder group. While the process may be as time-consuming as it will be emotionally charged, it is paramount to allowing the Indigenous and non-Indigenous peoples of Canada to interrogate thoughtfully and reflectively about what may in fact be previously unexamined attitudes.

\section{References}

Alfred, T. (2009). Restitution is the real pathway to justice for Indigenous peoples. Response, responsibility, and renewal: Canada's truth and reconciliation journey, 2.

Andersen, C., \& Denis, C. (2003). Urban Natives and the nation: Before and after the Royal Commission on Aboriginal Peoples. Canadian Review of Sociology/Revue canadienne de sociologie, 40(4), 373-390.

Berger, T. R. (1977). Northern frontier, northern homeland (Vol. 1). Ottawa: Mackenzie Valley Pipeline Inquiry.

Canada. Royal Commission on Aboriginal Peoples. Report of the Royal Commission On Aboriginal Peoples. Ottawa: The Commission, 1996.

Cherubini, L. (2014). Aboriginal Student Engagement and Achievement: Educational Practices and Cultural Sustainability. Vancouver, British Columbia: UBC Press.

Cherubini, L. (2018). Discourse and difference: An initial examination of Aboriginal education policy in Ontario. Alberta Journal of Educational Research, 64(3), 327-329.

Coulthard, G. S. (2007). Subjects of empire: Indigenous peoples and the 'politics of 


\title{
2nd world conference on research in SOCIAL SCIENCES
}

\author{
19-21 March, 2021
}

Budapest, Hungary

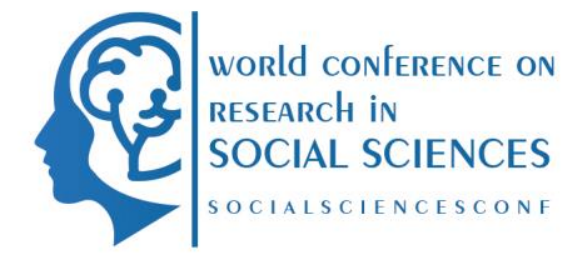

recognition' in Canada. Contemporary political theory, 6(4), 437-460.

Cutrara, S. (2018). The settler grammar of Canadian curriculum: Why historical thinking is unable to respond to the TRC's calls to action. Canadian Journal of Education, 41(1), 250-275.

Czyzewski, K. (2011). The Truth and Reconciliation Commission of Canada: Insights into the goal of transformative education. International Indigenous Policy Journal, 2(3).

Davis, L., Hiller, C., James, C., Lloyd, K., Nasca, T., \& Taylor, S. (2017). Complicated pathways: Settler Canadians learning to re/frame themselves and their relationships with Indigenous peoples. Settler Colonial Studies, 7(4), 398-414.

de Leeuw, S. (2017). Writing as righting: Truth and reconciliation, poetics, and new geographing in colonial Canada. The Canadian Geographer/Le Géographe Canadien, 61(3), 306-318.

Ermine, W. (2007). The ethical space of engagement. Indigenous L.J., 6(1), 193.

Freeman, V. (2014). In defence of reconciliation. Canadian Journal of Law \& Jurisprudence, 27(1), 213-223.

Henderson, J., \& Wakeham, P. (2009). Colonial reckoning, national reconciliation?

Aboriginal peoples and the culture of redress in Canada. ESC: English Studies in Canada, 35(1), 1-26.

Hughes, J. (2012). Instructive past: lessons from the Royal Commission on Aboriginal Peoples for the Canadian Truth and Reconciliation Commission on Indian residential schools. Canadian Journal of Law \& Society/La Revue Canadienne Droit et Société, 27(1), 101-127.

Hunt, S. (2014). Ontologies of Indigeneity: the politics of embodying a concept. Cultural geographies, 21(1), 27-32.

Hunt, S., \& Holmes, C. (2015). Everyday decolonization: Living a decolonizing queer politics. Journal of lesbian studies, 19(2), 154-172.

Indian and Inuit Affairs Program (Canada), \& Hawthorn, H. B. (1967). Survey of the Contemporary Indians of Canada. Economic, Political, Educational Needs and Policies.

Institute on Governance. (2015). Revisiting RCAP towards reconciliation: The future of Indigenous governance.

https://books.scholarsportal.info/en/read?id=/ebooks/ebooksO/gibson_cppc/2015-0325/1/11009606

Kumar, M. P. (2009). Aboriginal education in Canada: A postcolonial analysis. ALTERNATIVE: An international journal of Indigenous peoples, 5(1), 42-57

Lightfoot, S. (2015). Settler-state apologies to indigenous peoples: A normative framework and comparative assessment. Journal of the Native American and Indigenous Studies Association, 2(1), 15-39.

Lysyk, K. (2010). Approaches to Settlement of Indian Title Claims: The Alaskan ModelKenneth Lysyk. -Reprint. -1973.

Martin, K. (2009). Truth, reconciliation, and amnesia: Porcupines and China dolls and the Canadian conscience. ESC: English Studies in Canada, 35(1), 47-65.

McGregor, D. (2011). Aboriginal/non-Aboriginal relations and sustainable forest management in Canada: The influence of the Royal Commission on Aboriginal Peoples. Journal of Environmental Management, 92(2), 300-310.

Miller, J. R. (2019). Research and Outcomes at the Truth and Reconciliation Commission. Canadian Historical Review, 100(2), 163-181. 


\title{
2nd world conference on research in SOCIAL SCIENCES
}

\author{
19-21 March, 2021 \\ Budapest, Hungary
}

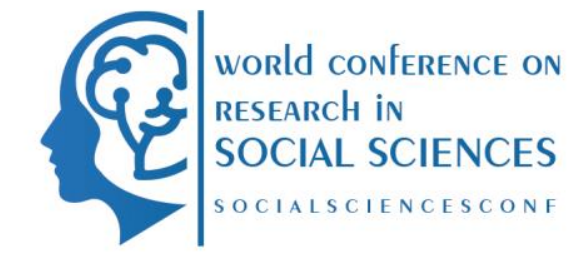

Nagy, R. (2012). Truth, reconciliation and settler denial: specifying the Canada-South Africa analogy. Human Rights Review, 13(3), 349-367.

Regan, P. (2010). Unsettling the settler within: Indian residential schools, truth telling, and reconciliation in Canada. UBC Press.

Reynaud, A. M. (2017). Emotions, Remembering and Feeling Better: Dealing with the Indian Residential Schools Settlement Agreement in Canada. transcript Verlag.

Rymhs, D. (2006). Appropriating guilt: Reconciliation in an Aboriginal Canadian context. ESC: English Studies in Canada, 32(1), 105-123.

Truth and Reconciliation Commission of Canada (TRC). (2015a). Canada's residential schools: Reconciliation. The Final Report of the Truth and Reconciliation Commission of Canada, Volume 6. Montreal, QC: McGill-Queen's University Press.

Truth and Reconciliation Commission of Canada (TRC). (2015b). Final Report of the Truth and Reconciliation Commission of Canada, Volume One: Summary: Honouring the truth, reconciling for the future. Toronto, ON: James Lorimer \& Company.

Truth and Reconciliation Commission of Canada (TRC). (2015c). Calls to action. Winnipeg, MB: Portage and Main Press.

Waterstone, M., \& de Leeuw, S. (2010). A sorry state: apology excepted. Human Geography, 3(3), 1-28.

Waziyatawin. (2009). You Can’t Un-Ring a Bell: Demonstrating Contrition through Action. Response, Responsibility, and Renewal: Canada's Truth and Reconciliation Journey, 193-99.

Weiss, J. J. (2015). Challenging Reconciliation: Indeterminacy, Disagreement, and Canada's Indian Residential Schools' Truth and Reconciliation Commission. International Journal of Canadian Studies, 51, 27-56. 